\title{
Exploring the role of design quality in the Building Schools for the Future programme
}

Article

Accepted Version

Cardellino, P., Leiringer, R. and Clements-Croome, D. (2009) Exploring the role of design quality in the Building Schools for the Future programme. Architectural Engineering and Design Management, 5 (4). pp. 249-262. ISSN 1745-2007 doi: https://doi.org/10.3763/aedm.2008.0086 Available at https://centaur.reading.ac.uk/11824/

It is advisable to refer to the publisher's version if you intend to cite from the work. See Guidance on citing.

To link to this article DOI: http://dx.doi.org/10.3763/aedm.2008.0086

Publisher: Taylor \& Francis

All outputs in CentAUR are protected by Intellectual Property Rights law, including copyright law. Copyright and IPR is retained by the creators or other copyright holders. Terms and conditions for use of this material are defined in the End User Agreement.

www.reading.ac.uk/centaur 
Central Archive at the University of Reading

Reading's research outputs online 


\title{
Exploring the Role of Design Quality in the Building Schools for the Future Programme
}

\author{
Paula Cardellino ${ }^{1}$, Roine Leiringer ${ }^{1}$ and Derek Clements-Croome ${ }^{1}$
}

School of Construction Management and Engineering, Whiteknights, Box 225, University of Reading, UK.

\begin{abstract}
The Building Schools for the Future (BSF) programme represents the biggest single UK government investment in school buildings for more than 50 years. A key goal for BSF is to ensure that pupils learn in 21st-century facilities that are designed or redesigned to allow for educational transformation. This represents a major challenge to those involved in the design of schools. The paper explores the conceptualizations of design quality within the BSF programme. It draws on content analysis of influential reports on design published between 2000 and 2007 and interviews with key actors in the provision of schools. The means by which design quality has become defined and given importance within the programme through official documents is described and compared with the multiple understandings of design quality among key stakeholders. The findings portray the many challenges that practitioners face when operationalizing design quality in practice. The paper concludes with reflections on the inconsistencies between how design quality has been appropriated in the BSF programme and how it is interpreted and adopted in practice.
\end{abstract}

Keywords - Building Schools for the Future; design quality; educational transformation; schools

\section{INTRODUCTION}

In the UK, the Building Schools for the Future (BSF) programme represents the biggest single government investment in improving school buildings for more than 50 years. The programme aims to drive reform in the organization of schooling, teaching and learning, and in the procurement of school buildings. The stated target is to achieve educational buildings that inspire new ways of learning and to provide 'excellent' facilities that benefit the whole community. This is to be achieved by rebuilding or refurbishing every secondary school in England over a period of 10-15 years (DfES, 2004a). The initiative comes on the back of an increasingly widely held belief that older schools, as well as those more recently built or refurbished, are inadequate in their ability to cope with anticipated changes such as shifting pedagogy, curriculum and learning expectations (Audit Commission, 2003). There is, as such, a clear recognition that the public sector must be provided with environments that provide children with good places to learn and that schools should be designed to the 
highest quality (e.g. CABE, 2006a). In this context, the term 'design quality' has been given great prominence (CABE, 2003; DfES, 2004a; CABE, 2006a, 2006b; OGC, 2007). The purpose of this paper is to explore how design quality has been appropriated in the BSF programme and how it is interpreted and adopted in practice.

The first section of the paper documents the aims and objectives of the BSF programme, while the second section examines the vast academic literature on design and the links between design and various aspects of performance. Particular attention is given to the debate surrounding the influence of good design on education. The third section notes that design has played a part in previous educational reform programmes and then goes on to explore the role of design in the current debate within the BSF context. This is followed by a description of the adopted research method. The findings are presented in two parts. The first presents formal descriptions of design quality provided in a variety of official reports published between 2000 and 2007. The second part contrasts these formal descriptions with the views of a variety of stakeholders to the BSF process. The ambiguities inherent in the interpretations of design quality and the problems of operationalizing it are highlighted. The concluding discussion focuses on inconsistencies in how the components of design quality, as put forward in the official documents, are interpreted among different programme stakeholders.

\section{THE BUILDING SCHOOLS FOR THE FUTURE PROGRAMME}

The BSF programme represents the biggest investment in English educational infrastructure since immediately after the Second World War. It was launched by the then Department for Education and Skills (DfES) in February 2003. The scope of the programme comprises the rebuilding or refurbishing of every secondary school in England by 2020, with the public investment in school buildings predicted to reach $\mathrm{f} 45$ billion (Education and Skills Committee, 2007). The programme was established on the back of rising investment in schools through the private finance initiative (PFI) during the period 1997-2003. Increasingly, concerns had been raised regarding the quality and cost of the schools procured through PFI (Audit Commission, 2003). BSF was thus put in place not solely as a financing route for new school buildings, but as a vehicle to ensure that schools are designed or redesigned to allow for educational transformation. Indeed, the programme approach was considered to create an opportunity to transform the way secondary schools function, by developing buildings for the 21st century with teaching and learning to match (CABE, 2006b). In accordance, the documented aims of the BSF are to provide schools that:

- improve learning and achievement for every child and young person

- use new thinking and opportunities and be 
- creative in designing for learning

- enhance school diversity and parental choice

- increase the use of schools by the community

- seize opportunities through new technologies

- produce places for learning that are exciting, flexible, healthy, safe, secure and environmentally sustainable (4ps and Partnerships for Schools, 2007).

Thus, the programme aims to account for current and future developments in education, technology and society. Ultimately, the target is to achieve educational environments that inspire new ways of learning and to provide 'excellent' facilities that benefit the whole community (4ps and Partnerships for Schools, 2007). A fundamental part of the programme is the commitment to design quality (DfES, 2004a; 4ps and Partnerships for Schools, 2007; CABE, 2007; NAO, 2009). One materialization of this commitment is the mandatory use of the design quality indicators (DQIs) on all new-build projects (CABE, 2007).

In summary, state-of-the-art buildings are proposed as a means of improving educational standards. The fact that such facilities have a positive effect on pupils, teachers and the wider community is clearly stated in a number of publications (CABE, 2002; Building Futures, 2004; DfES, 2004b; CABE, 2006b). So too is the belief that good design facilitates efficient school environments (CABE, 2007). And this in turn is presented as a necessary step-change in the process of educational transformation (DfES, 2004c).

\section{LINKING DESIGN QUALITY AND EDUCATION}

Design is a functional expertise that holds apart, but also brings together, the craft of making and the experience of using. It involves multiple specialist professions, with different norms and values, working in complex organizational arrangements and responding to specific clients, as well as to professional institutions and government policies and regulations. The meaning and significance of specific aspects of design will therefore vary among different stakeholders. Benedikt (2007), for example, highlights the contexts in which judgments are made and discusses criteria for the evaluation of architecture in those contexts. He notes how for architects, professional esteem is gained through criteria for assessing the building such as 'significance and uniqueness of programme', 'composition or formal freshness', 'mastery of some new technology', 'fineness of construction' and 'narratability'; while the public uses criteria such as 'liveability', 'contextuality', 'classiness', 'price' and 'goodness for the local economy' in the evaluation 
of both architects and their buildings. Thus, an evaluation of the quality of design can emphasize different aspects of its role: for example, the manufacturability of the design; the usability and experience of using the final product; or the forms that are marked out and generated themselves and their relation to other designs.

At the more detailed level, design quality is frequently treated as a multifaceted phenomenon. This has been recognized, at least, since late Antiquity, when Vitruvius described design as a tripartite division of firmitas, utilitas and venustas, terms often translated as commodity, firmness and delight (Vitruvius, 1999). The concepts of function, build quality and impact are a modern-day interpretation of the Vitruvian framework (Gann et al, 2003). 'Function' includes concepts such as the building use, access and space; 'build quality' relates to the building performance and construction; and 'impact' encompasses aspects of the building form and materials, internal and external environment and identity.

\section{DESIGN AND SCHOOLS}

Studying the impact of the built environment on performance has a long tradition (e.g. Herzberg, 1966). A plethora of benefits associated with a well- designed built environment and the impact of good design on social and economic outcomes have been put forward (cf. Macmillan, 2004). A significant amount of these studies have focused on the commercial and industrial workplace, with recent publications (e.g. Clements-Croome, 2004, 2006) providing seemingly compelling arguments for the existence of strong links between the built environment and productivity. Yet, it is also increasingly recognized that the value of intangible benefits from well-designed buildings is difficult to capture and assess (Macmillan, 2006).

In the education domain, a number of studies have sought to establish a relationship between the nature and quality of the physical environment in which students learn and the learning outcomes (e.g. Weinstein, 1979; Gump, 1987; Tanner, 2000; Fisher, 2001; Clark, 2002; Green and Turrell, 2004; Higgins et al, 2005). Several aspects of the physical school environment are linked with improved levels of teaching and learning. Yet, while there is a clear link between the improvement of poor learning environments and improvements in pupils morale, motivation and attainment (Earthman, 2000; Feilden, 2004), the benefits of improving already adequate environments for teaching and learning is less evident. Once a minimum standard is achieved, the degree to which explicit links exist and the exact influence that they have remains a matter of debate (cf. Higgins et al, 2005; Woolner et al, 2005).

To no small extent, the difficulty of establishing strong correlations can be attributed to schools 
being complex systems (cf. Gifford, 2002). The relationships between people and their environment are multifaceted in nature and as noted by Proshansky et al (1976: 5) 'the physical environment that we construct is as much a social phenomenon as it is a physical one'. In order to reduce complexity, environmental psychologists classify the 'total' environment into three parts: physical, social and cultural (Horne-Martin, 2004). From this perspective, schools are systems in which the buildings are just one of many interacting factors, examples of others are pedagogical, socio-cultural, curricular, motivational and socio-economic. Those involved in the design and delivery of the school will mainly be concerned with the physical aspect of the building.

\section{THE ROLE OF DESIGN IN THE BSFPROGRAMME}

The idea that there is a link between school building design and changes in teaching approaches is by no means new. The UK has seen several more or less failed attempts to centrally impose a change in the national curriculum (cf. Brogden, 2007), some of which have been directly linked to innovative designs. One such attempt was the open-plan movement in the 1970s (Bennett et al, 1980), which was described by contemporary commentators as representing innovation without change (e.g. Adelman and Walker, 1974). The teachers were at the time portrayed as reluctant, and partially incapable, to move away from traditional teaching methods (Brogden, 2007).

Notwithstanding, recent public sector studies, such as those commissioned by the UK Department for Education and Skills (PwC, 2001; 2003), state that capital investment in school buildings has a measurable positive influence on staff morale, pupil motivation and effective learning time. These findings are, however, not without their critics. Studies on the impact of individual elements of the physical environment and the implications for the design of BSF schools have reported that beyond the necessity of meeting basic standards there is not enough evidence to give clear advice to policymakers on how to set priorities for funding (e.g. Woolner et al, 2005). Instead, it is argued that expectations regarding the impact on educational transformation through the delivery of physical environments must be based on the understanding of the complexity of the schools (Woolner et al, 2007). This line of argument is further supported by Higgins et al (2005) who found consistent evidence for the effect of basic physical variables (e.g. natural ventilation, colour, temperature) on learning, although once minimal standards are achieved the effect is less significant. In other words, individual physical characteristics affect student perceptions, but it remains difficult to draw comprehensive conclusions of how and to what extent. Different schools, children, cultures and contexts will at different times create a variety of conditions for potential learning. 
The BSF programme has since its launch undergone a number of reviews assessing the ability of the programme to deliver educational transformation through the delivery of 21st century facilities (Education and Skills Committee, 2007; PwC, 2007, 2008; NAO, 2009). In 2006, the Department for Children, Schools and Families (DCSF) initiated a longitudinal review with the aim of measuring the educational impact of BSF capital investment in secondary schools. In the most recent report from this review (PwC, 2008), it is concluded that there is insufficient evidence of the design of new buildings, including flexible teaching areas, having significantly contributed to changing pedagogy in practice.

Thus, at present, there are still concerns regarding the BSF's effectiveness in improving the quality of education (NAO, 2009). The following sections explore the means by which design quality has become defined and given importance within the BSF programme through official documents and the multiple perceptions of design quality that stakeholders have in practice.

\section{METHOD}

This paper draws on research conducted in 2006-2008 that studied design practices and processes in the context of the BSF programme. The data presented here were collected and analysed in two major phases:

- establishing a formal description of design quality through an analysis of BSF-related documents and reports

- exploring the perceptions of design quality inpractice through interviews and informal discussions with experienced professionals representing key actors in the provision of schools.

The first phase took as its starting point official reports from the period 2000 to 2007 that dealt explicitly with design issues. The resulting list consisted of 40 reports primarily targeting design quality in buildings and design quality in schools. The reports were predominantly from the UK complemented with a small sample of international reports. While not being a fully comprehensive list of all the publications during this time, the reports included have all been cited by the BSF as relevant to the programme's objectives. For each report, key perspectives on design were identified with particular focus given to the achievement of design quality. A second round of analysis was then undertaken focusing solely on the reports explicitly addressing aspects of design quality in schools. This narrowed down the sample to nine reports (presented in Table 1) all of which have a firm place in the BSF discourse. These reports were analysed on the basis of establishing the key tenets of design quality in schools in the BSF context. 


\section{TABLE 1 Reports addressing aspects of design quality in schools}

\begin{tabular}{|c|c|c|c|}
\hline PUBLICATION & $\begin{array}{l}\text { COMMISSIONING } \\
\text { BODY, YEAR }\end{array}$ & $\begin{array}{l}\text { KEY CRITERIA OF QUALITY } \\
\text { SCHOOLS }\end{array}$ & SUMMARY OF CONTENTS \\
\hline Schools for & Department for & Fitness for purpose & \multirow{9}{*}{$\begin{array}{l}\text { Presents detailed guidance on the design } \\
\text { of 21st-century schools illustrated } \\
\text { with case study examples. Design quality } \\
\text { is defined as a combination of: sustainability, } \\
\text { flexibility and adaptability and value for money }\end{array}$} \\
\hline the Future: & Education and Skills & Flexibility and & \\
\hline Designs for & (DfES), 2002 & adaptability & \\
\hline Learning & & Build quality & \\
\hline Communities. & & Efficiency & \\
\hline Building & & Aesthetically & \\
\hline \multirow[t]{3}{*}{ Bulletin 95} & & pleasing & \\
\hline & & Sustainability & \\
\hline & & Buildability & \\
\hline Schools for & DfES, 2004b & Flexibility and & Presents case studies showing exemplar designs \\
\hline the Future: & & adaptability & putforward to beadapted to futureschool design. \\
\hline exemplar & & Sustainability & Themes include: inspiration and innovation; a \\
\hline designs, & & Comfort & school for us and the community; schools for \\
\hline concepts and & & Inspirational & today and ideas for tomorrow; flexibility and \\
\hline \multirow[t]{3}{*}{ ideas } & & Innovation & adaptability; linear and learning clusters; indoor \\
\hline & & & courtyards and outdoor classrooms; comfort and \\
\hline & & & sustainability \\
\hline Briefing & DfES, $2004 c$ & Fitness for purpose & Identifies good design as a mix of the following \\
\hline Framework & & Build quality & attributes: functionality in use; build quality; \\
\hline for Secondary & & Efficiency & efficiency and sustainability; designing in context; \\
\hline School Projects: & & Sustainability & aesthetic quality; and the need for a non- \\
\hline Building & & Aesthetically pleasing & institutional, individual character \\
\hline \multirow[t]{2}{*}{ Bulletin 98} & & Contextual fit & \\
\hline & & Individuality & \\
\hline 21st Century & Building Futures, & Flexibility & Argues that the transformation in education has to \\
\hline Schools, & 2004 & Inspirational & be supported by the school facilities. For this to \\
\hline Learning & & Supportive & happen, school facilities are to be designed to be: \\
\hline Environments & & Involving & flexible; inspiring; supportive; and involving. The \\
\hline \multirow[t]{3}{*}{ of the Future } & & & report introduces the DQI tool and its tripartite \\
\hline & & & approach to design quality as an effective way to \\
\hline & & & assess a school building \\
\hline 21st Century & Organization & Fitness for purpose & Presents case studies to illustrate how different \\
\hline \multirow[t]{7}{*}{ Learning Environments } & for Economic & Flexibility & countries define and use innovative design in \\
\hline & Cooperation and & Sustainability & schools. The report argues that design quality can \\
\hline & Development (OECD), & Accessibility & be assessed by the school building's fitness for \\
\hline & 2004 & Inspirational & purpose, sustainability, accessibility, flexibility, \\
\hline & & Comfort & inspiration, comfort and safety. It also argues for a \\
\hline & & Safety & general quality model to reflect the views of the \\
\hline & & & different stakeholders \\
\hline Picturing & Commission for & Functionality & The report is a visual guide to secondary school \\
\hline \multirow[t]{4}{*}{ School Design } & Architecture and & Build quality & buildings and their surroundings using the design \\
\hline & the Built Environment & Impact & quality indicator for schools. Design quality is \\
\hline & (CABE), 2005 & & viewed as a combination of: functionality; build \\
\hline & & & quality; and impact \\
\hline
\end{tabular}


TABLE 1 Reports addressing aspects of design quality in schools (Cont'd)

\begin{tabular}{|c|c|c|c|}
\hline PUBLICATION & $\begin{array}{l}\text { COMMISSIONING } \\
\text { BODY, YEAR }\end{array}$ & $\begin{array}{l}\text { KEY CRITERIA OF QUALITY } \\
\text { SCHOOLS }\end{array}$ & SUMMARY OF CONTENTS \\
\hline Assessing & \multirow[t]{4}{*}{ CABE, 2006b } & Fitness for purpose & Assesses the design of a sample of secondary \\
\hline Secondary & & Flexibility & schools completed between 2000 and 2005 using \\
\hline Schools & & Sustainability & a variation of the design quality indicator (DQI). \\
\hline Design Quality & & $\begin{array}{l}\text { Aesthetically pleasing } \\
\text { Inspirational } \\
\text { Contextual fit } \\
\text { Accessibility } \\
\text { Clear organization } \\
\text { and layout }\end{array}$ & $\begin{array}{l}\text { Theschooldesignisassessedthrougha10-point } \\
\text { checklist:good clear organization, aneasilylegible } \\
\text { plan; spaces that are well-proportioned, efficient, } \\
\text { fit for purpose and meet the needs of the } \\
\text { curriculum; circulation that is well organized; good } \\
\text { environmental conditions; attractiveness in design } \\
\text { toinspirepupils,staffand parents; gooduse of the } \\
\text { site and public presence as a civic building to } \\
\text { engender local pride; attractive external spaces } \\
\text { with a good relationship to internal spaces; a } \\
\text { layout that encourages broad community access; } \\
\text { robust materials that are attractive; and flexible } \\
\text { design }\end{array}$ \\
\hline PEB Compendium & \multirow[t]{5}{*}{ OECD, 2006} & Flexibility & Presents 65 educational facilities around the world \\
\hline of Exemplary & & Community needs & chosen for their fitness for purpose using the \\
\hline Educational & & Sustainability & following criteria: flexibility, community needs, \\
\hline Facilities: & & Safety and security & sustainability, safety and security, and alternative \\
\hline 3rd edn & & Alternative financing & financing \\
\hline Creating & \multirow[t]{8}{*}{ CABE, 2007} & Flexibility & Introduces CABE's 10 key points used to assess a \\
\hline Excellent & & Efficiency & good design, where a high-quality design involves \\
\hline Secondary & & Sustainability & a sustainable approach; good use of the site; \\
\hline Schools. & & Contextual fit & buildings and grounds that are welcoming; good \\
\hline \multirow[t]{4}{*}{ A Guide for Clients } & & Accessibility & organization of spaces; internal spaces that are \\
\hline & & Clear organization and layout & well proportioned; flexible design; good \\
\hline & & Aesthetically pleasing & environmental conditions; well-designed external \\
\hline & & & spaces; and a simple palette of attractive materials \\
\hline
\end{tabular}

In the second phase of the research, 17 semi- structured interviews were conducted with representatives of some of the key participants in the BSF process. The specific purpose of these interviews was to establish individual concerns, perceptions, reactions, observations and thoughts in connection with design quality in the BSF programme. The interviewees could be divided into two broad groups. In the first group were senior representatives of the following organizations: Partnerships for Schools (PfS) - the government agency charged with the delivery of the BSF programme; Department for Children, Schools and Families (DCSF); Construction Industry Council (CIC) - involved in the development of the DQIs; Commission for Architecture and the Built Environment (CABE); and the Building Research Establishment (BRE). The second group consisted of representatives of architectural studios, consulting engineers and contractors; these interviewees were all at a senior manager or director level. An interview schedule was used to guide the interviews 
that typically lasted between one and two-and-a-half hours. The interviewees were asked about their experiences in school design in general and in the BSF in particular, their personal views on design quality and their perceptions on the achievement of design quality in the BSF programme. Each interview was transcribed and comparative analysis was undertaken.

\section{ESTABLISHING THE PRINCIPLES OF DESIGN QUALITY}

As previously mentioned, design advice from the UK government is not a new phenomenon. Such advice can easily be tracked back to the period immediately after the Second World War and the Ministry of Education's Building Bulletins (cf. Dudek, 2000). Nonetheless, the past decade has seen an increase in the number and frequency of publications addressing the importance of achieving design quality in buildings (e.g. DCMS, 2000; CABE, 2002; CABE, 2003; CABE, 2006a; OGC, 2007) and in schools (e.g. DfES, 2004a; CABE 2006b; CABE, 2007). This growing literature highlights the importance of design quality, presents the attributes of a welldesigned building, introduces exemplars of design quality and provides advice on how design quality can be achieved.

An important aspect of how design quality is conceptualized in these documents is the consideration of its implication at different levels, gradually focusing in from the overall environment to the design details of the building. It is advised that good design should be sought at all levels of the project; in the context of the site and its environment, in the facility as a whole and in the small details (e.g. OGC, 2007).

As shown in Table 1, the reports converge towards a set of core tenets of design quality that can be categorized into: fitness for purpose (or functionality), efficiency and sustainability, build quality, flexibility and adaptability, aesthetically pleasing, contextual fit, inspirational, accessibility, and safe and secure environments. These are briefly presented below.

\section{FUNCTIONALITY AND FITNESS FOR PURPOSE}

A functional school building is one that through its design addresses present and future changes in pedagogy (e.g. DfES, 2002; Building Futures, 2004; OECD, 2004). That the building is 'fit for purpose' is viewed as a crucial component of design quality and vital to the achievement of a good school building. This concept is given significant prominence in the BSF and it relates closely to the Government's expressed policy that the investment in secondary schools is not just about providing new buildings, but also about acting as a channel for educational transformation. In particular, the recent educational agendas on 'every child matters' and 'personalized learning' are seen as very influential (CABE, 2007). 


\section{FLEXIBILITY AND ADAPTABILITY}

Past approaches to school design are deemed to have hindered the ability of adapting the building to future needs in education (Building Futures, 2004). Designing flexible environments is believed to enable the adoption and adaption of the emerging changes in education (e.g. DfES, 2004c). Thus, flexible and adaptable building designs 'future proof' the spaces and allow for a variety of uses at different points in time (CABE, 2006b). Furthermore, it is suggested that flexible or 'agile' designs will allow for short-term changes of layout and use, and for long-term expansion or contraction (Building Futures, 2004). However, the need to strike a balance between flexibility and specificity and the functional aspects of the school (teaching areas) and social spaces are also explicitly expressed (Building Futures, 2004; CABE, 2006b).

\section{INSPIRATIONAL, SAFE AND SECURE}

Inspirational school buildings are supportive of effective teaching and learning and inspire users to learn (DfES, 2004b; OECD, 2004; CABE, 2005, 2007).

The ultimate aim is for spaces that foster creativity and a culture of learning. The design of learning environments that have something unique about them will make these spaces special - 'spaces' that become 'places' (CABE, 2006b). This is believed to be achieved through the design of environments that accommodate a wide range of experiences and activities and that include all types of learning: intellectual, physical, practical, social, emotional, spiritual and cultural (Building Futures, 2004). In other words, inspirational buildings support a diversity of learners and inspire not only the pupils, but also those who work and visit the school.

The design of the learning environment should also embody the aims and principles of the school (DfES, 2004b). The building should 'tell' the users what the building is about, but should not be threatening. A school building that is safe and secure will be one that encourages good behaviour and can be easily managed (DfES, 2002; OECD, 2004, 2006).

\section{AESTHETICALLY PLEASING AND CONTEXTUAL FIT}

A building is considered to be 'beautiful' when it 'lifts the spirits' of those who come into contact with it (CABE, 2007). An aesthetically pleasing building is portrayed as not only having the potential to create a 'sense of place' in the internal school environment, but also as having a positive effect on the local community (CABE, 2006a). Likewise, a school that is welcoming and accessible is portrayed as having a positive impact not only on the users of the building, but also on the surrounding areas (DfES, 2002; CABE, 2006b). For example, an 
attractive entrance and a welcoming hall contribute to a positive visual impact on the local neighbourhood (CABE, 2006b). As such, contextual fit goes beyond the specific school environment and places emphasis on the interaction with and contribution to the local community and public well-being in general (DfES, 2004c; CABE, 2006b).

\section{BUILD QUALITY AND SUSTAINABILITY}

Build quality is a concept that speaks for itself and sustainability is a topic that cannot be meaningfully dealt with in the confines of this paper. Nevertheless, important to the argument presented here is that well-designed learning environments should provide a platform for wider learning agendas ranging from the issues of citizenship and sustainability. For example, CABE (2006b) presents the sustainable character of the building, in terms of the use of natural light and ventilation, the consideration of alternative forms of energy and the choice of robust materials from sustainable sources, as a means to highlight and disseminate environmental issues.

\section{DESIGN QUALITY IN PRACTICE}

From the above analysis, it is clear that several of the attributes of design quality are of a subjective nature and will be given varying importance by different stakeholders in the BSF programme. It goes without saying that stakeholders such as contractors, architects, representatives of government bodies and consultants have a significant impact on the materialization of design quality. The following section explores these stakeholders' perceptions of what the important attributes of good design are and how they are operationalized in practice:

I think design quality is really interesting and generally very misunderstood. And I think CABE keep trying to describe to people what design quality is, and it keeps being misheard. (Architect 1)

What is good design? Obviously there are different views because there always will be in an industry. But I'm sorry to say, that rock bottom is, I just do not think many people would know a good design even if it hit them in the face like a wet fish. Therein lies the problem. (Contractor 1 ) 


\section{FITNESSFOR PURPOSEANDEDUCATIONAL TRANSFORMATION}

Achieving educational transformation through the refurbishment and construction of secondary schools is the foremost goal of the BSF programme and ultimately this is the criteria against which success will be measured. In this respect, there is unanimous agreement regarding the necessity of understanding the educational nature of the school and the physical environment of the building. Several government bodies address the importance of considering and accommodating the new teaching and learning agendas, such as 'every child matters' and 'personalized learning' in the school design:

I think we are aware that actually we are designing schools that are 20th century schools rather than 21st century schools in the sense that they are still largely departmentally organized and so on, rather than organized in a freer form that a personalized learning might determine. (DfES representative)

Thus, there is a belief that the introduction and implementation of these educational approaches to various degrees are dependent on the design of school buildings. Yet, there is real concern regarding the ability of those involved in the design process to address the rapidly changing pedagogies. The ability to predict and visualize the way in which the pedagogy will change in the future is seen as a major challenge:

One of the big challenges is that there has been a fairly determined pedagogy in school design for the last 20 to 30 years. What seems to be happening now is that because the pedagogy is breaking down, becoming more fluid, it is very difficult to visualize what that form might look like. (CIC representative)

This quite clearly has a significant impact on any judgement of the 'fitness for purpose' of the school building. Of particular concern and frequently mentioned was the difficulty in achieving educational facilities that are not only functional at present, but that will also be able to address future changes in pedagogy. Notwithstanding these concerns, fitness for purpose was prevalent in descriptions of design quality and was put forward as an important aspect of school design. Indeed, it was considered by all interviewees to be pivotal to the achievement of a good school. However, this unanimous agreement was to a great extent a result of individual sense-making, as the opinions of how fitness for purpose is defined, varied between the respondents. This was especially the case when the issue was discussed in the context of educational transformation. This reflects what was described as a continuous discussion between suppliers and clients regarding the meaning of the educational transformation and what it entails: 
Is transformation a kid that would only have got an ' $E$ ', getting a ' $B$ ', ' $C$ ' or ' $D$ '? Or is transformation the regeneration of a community? It is just so loose! What is the [meaning of the] statement of BSF apart from to replace some of the schools and have some inspirational transformational designs? It is very woolly. It means so many things to different people. Ultimately, I think people just want better schoolsfor our kids to learn in. (Contractor 2)

Contractors and architects held similar views regarding the role that the school building plays in educational transformation. Although extremely aware that changes in education will have an impact on the building design, they were in doubt about the extent to which the building would impact on the attainment of educational goals. The building was portrayed as but one component of the school environment. While continually asked to deliver transformation within the BSF programme, they felt they were limited in the level of transformation they would be able to provide:

There is a lot of focus in the BSF world about transformation, so the whole programme is about transformation. We as architects are continually asked 'what are you going to do to deliver the transformation?'. We can only do so much. The new building is a component of the school, is part of the school. It is not the school. The school is the people, the pupils, the teachers. (Architect 2)

In general, the opinion expressed was that the suitability of a new building is intrinsically related to other components of the school system, such as the end-users. As such, concern was raised regarding the end-users buying into the education transformation discourse. Judgements of fitness for purpose were therefore seen as directly linked to the way in which teachers will use the spaces and their attitudes towards the transformation:

There is this tension about transforming education and human nature not wanting to change, so there will always be those tensions in local authorities, and I suppose it is their choice as to whether they say, 'we are going for transformation and we are going to drag our teachers with us', or whether they do not. (Contractor 1 )

The common conclusion was that fitness for purpose can only be achieved through more participation of the teachers in the process and the provision of sufficient funds to educate users on how to use the building. 


\section{FLEXIBILITY AND ADAPTABILITY}

Within the BSF, the design of flexible learning environments is considered crucial in enabling the implementation and adoption of different approaches to education. The 'every child matters' agenda is founded on an acceptance that each pupil is an individual and therefore will learn in a different way. This requires the design of flexible spaces:

So the different ways of learning are suggesting that actually there is a different way of designing some of these spaces, which gives us the flexibility to do far more than we can do in just classrooms. People talk about pedagogies - different ways of learning. Actually, accepting that we might learn differently, at a different pace, and have different interests. (PfS representative)

These ideas had also been adopted by the second group of interviewees. They highlighted the importance of flexibility in the school building in accommodating present and future pedagogical approaches:

I think the design features for me that I am finding to be most important are flexibility and adaptability. Introducing a variety of spaces in the schools... It is about trying to respond to the fact that schools are no longer just classrooms and corridors. (Architect 3)

Designing flexible buildings was here interpreted as introducing a variety of alternative spaces. However, in their accounts the interviewees kept returning to the difficulties of conceptualizing and accommodating potential unpredicted changes. Indeed, understanding the ongoing changes and the uncertainties in the educational sector and addressing this from the outset of the building design is by no means a trivial task. Unsurprisingly, therefore, the different actors had different ideas for how flexibility and adaptability could be achieved:

We always talk about adaptability rather than flexibility. Because flexibility is quite expensive in terms of if you are looking to reconfigure rooms during the day or the week, those screens are quite expensive and they don't work that well. You can pay a lot of money and still hear noise. In some other schools, they specifically ask for that and we put it in. But we try to promote more adaptability so you can knock a wall down relatively easily and make the room bigger. (Architect 4)

Among the architects this issue was addressed primarily by arguing for the need to include in the school building a combination of different spaces that can be easily adapted to address the individuality of the pupils. Flexible spaces are those that can be easily transformed to accommodate the day-to-day changes in pedagogy. Long-term changes are addressed by the adaptability of the design. 


\section{THE CHARACTER OF THE BUILDING}

The idea that the building should be aesthetically pleasing was prevalent among the architects. Yet, the rest of the interviewees were less enthusiastic about this aspect of design quality and concerns were raised regarding the benefits of designing overly 'fancy' buildings. The contractors and the consultants, in particular, considered these to cost too much and have minimal, if any, impact on learning. In their view, many architects produce superficially attractive and glitzy buildings, and are lacking in their ability to relate to the physical spaces needed to deliver the educational transformation required:

You have got some quite interesting buildings. But are they good value for money? Probably not. Are they architecturally pleasing? Yes. But then are they overly architecturally pleasing? Probably. So the client pays for that. (Contractor 2)

It was argued that the use of images of award- winning school buildings in the reports, at times, served to put excessive emphasis on the aesthetic aspects of the buildings and divert attention from education. Those involved at the programme level were, of course, not oblivious to this and they too had concerns about spending the allocated money merely on 'landmark' buildings. The architectural design of a building is only one aspect of the school and they were adamant about the allocated money being spent on good educational facilities:

It is about enabling maximum impact on education achievement: that is what it is about, that is what we are trying to get out of it. It is not pretty buildings, it is not big architecture awards, it is actually 'kids are doing better, kids are moving on to better things'. (PfS representative)

That said, there was still a strong belief that a positive perception of the school building impacts on the pupils' ability to learn. This belief was shared across the whole interviewee sample. So too was the view that an inspirational building benefits the individual as well as the community. In particular, the design of inspirational spaces was frequently portrayed as something that enables individual development:

So the idea is making places for people to be, and to grow and to learn and the idea of having good design that gives you, you know, light and views and opportunity to be an individual and all these kind of things, and not just institutional boxes with slamming doors. (Architect 1)

Creating a 'sense of place' within the school environment was acknowledged as an important aspect of design quality. The creation of this feeling of belonging within the school is, therefore, not only a building matter. Different schools, children and contexts will 
create a variety of conditions for this to happen. The architects were committed to creating designs that encourage social interaction between pupils and staff. Their descriptions of how this was to be achieved within the school building tended to be quite emotive and used analogies such as 'special spaces' and the 'heart of the school'. However, concerns were raised about the restrictions encountered when attempting to include special spaces into the school design:

The vision is often an education vision, so it is very slanted towards education. They will say 'must have sufficient social spaces' but the problem is that nowhere in Building Bulletin 98 or 99 does it give you an area for social spaces. (Architect 3 )

To the architects, the guidelines provided in BB98 were seen to constitute the minimum accepted standards for a school facility that, in their opinion, all too often were used as criteria for assessing costs. In contrast, the contractors and the consultants, rather pragmatically, highlighted the importance of prioritizing the aspects that are most important to the individual school. Their priorities, regarding contextual fit and their views of the potential impact of the school on the individual and the wider community, differed from those of the architects. From their point of view, the money allocated to building a school facility is not enough:

We have got to spend the money where it is best spent, so if it needs a really welcoming opening entrance and the entrance needs to look big and really welcoming and everything else, we will spend a bit of money there. But perhaps the back of the house might not be so 'wazzy' and when you get to classrooms at 60 square metres a classroom, there is only so much you can do with them, isn't there? So the point is trying to design those as best you can. So it is knowing where the best place to spend the money is, and perhaps where it's not so critical, to give the client at the end of the day exactly what they want. (Contractor 3)

\section{DISCUSSION AND CONCLUDING REMARKS}

Design quality has a prominent place in the BSF discourse. The significance of design quality is clearly articulated in the official documentation and advice on how to achieve it is provided in abundance. However, the reports fall somewhat short in describing how design quality can be fostered to achieve educational transformation. While several reports set out the attributes of a well-designed school, scant attention is commonly given to the commercial context. The majority of the reports target the architectural aspects of the building design and prescribe an architectural approach towards the assessment of design quality. To a degree this could be argued to be due to the great prominence and frequency of CABE reports. 
However, it should be remembered that CABE was specifically commissioned by the Government to provide advice on good design in public building projects (CABE, 2006a; HM Government, 2006). Hence, it is not surprising that these reports and the interpretations of design quality offered within them have had a significant impact. A notable example of the dominance of the architectural approach in the reports is the tendency to describe design quality using the tripartite approach to design. In particular, this approach is prevalent in the categories for assessing the design quality of school buildings set out in the DQI framework. The compulsory use of the DQI tool has successfully cemented the commitment to design quality in the programme and has had a significant impact on working procedures. However, the architecturally biased approach seemingly underestimates the value of intangible aspects of design and chances are that the tool becomes a 'tick the box' exercise.

The fact that the language used in the users' brief is educationally contextualized further serves to facilitate different interpretations among those involved in the design process. It falls on the architect to translate the educational concept or vision, presented in the users' brief, into the school design. Yet, the educational visions are by their very nature biased towards education and are not easily translated into the design of school buildings. It could, therefore, be argued that aspirations of educational transformation are best managed through active involvement and support of school staff in the design process. Indeed, throughout the study concerns were consistently raised about user participation being partially lost in the BSF and, more importantly, that it was by no means easily achievable. This concern and the importance given to the issue is mirrored in several reports in which it is commonly stated that a truly 'fit for purpose' educational facility can only be achieved through more participation of the teachers in the process (e.g. DfES, 2004c). While it is difficult to argue against such a statement, the grounds for the calls for more user participation in the design process among our interviewees could at least partially be derived from elsewhere. In no small way they reflect the significant risks at play. In particular, that the design has to be suitable for current and future changes to educational methods. The design of a school can be very exciting for present users but there remains a very real risk that future users may be inclined to use traditional teaching methods for which the school is not designed. The importance given to allocating funds to educate users on how to use the building reflects and offers a viable solution to the need to mitigate this risk.

The main criticism usually offered of design quality in the literature is that many of the attributes, at times, are trivial and based on advocacy rather than evidence was clearly reflected in our interview data. Numerous attributes of design quality were considered to be quite subjective and were given varying importance by different stakeholders. This was particularly apparent for attributes such as aesthetically pleasing and contextual fit. Different views and expectations concerning the school environment clearly exist. 
Omnipresent was the expressed need to view the design quality of a school as incorporating more than just the building. But so too was the difficulty of giving sufficient allowance to the commercial context in any judgement of quality of the design. Thus, it is not surprising that the practitioners frequently emphasized the challenges they face in attempting to operationalize notions of design quality. While there is common acceptance of the complexity of designing a school, agreement regarding the importance of the different components of the school system and how to prioritize between them is still to be achieved. The multiple purposes of educational facilities and the conflicting views of design quality combine to make finding a balance between 'fitness for purpose', 'cost effectiveness', 'buildability' and 'contextual fit' of the facility a very difficult task indeed. We hope that we have done justice to the complexity of this task as well as the sophistication of the thinking in the many reports on design quality. Ultimately, the BSF programme presents an unprecedented opportunity for institutional change.

\section{ACKNOWLEDGEMENT}

This paper is derived from a research project funded by the UK Engineering and Physical Sciences Research Council (EPSRC) through the Innovative Construction Research Centre (ICRC). Grant Reference EP/E001645/1. 


\section{REFERENCES}

4ps and Partnerships for Schools, 2007, An Introduction to Building Schools for the Future, London, Department for Children, Schools and Families.

Adelman, C. and Walker, R., 1974, 'Open space - open classroom', in Education, 3-13:

international Journal of Primary, Elementary and Early Years Education, 2(2), 103-107.

Audit Commission, 2003, PFI in Schools, London, Audit Commission. Benedikt, M., 2007, 'Introduction', in W.S. Saunders (ed), Judging Architectural Value: A Harvard Design Magazine Reader, Minneapolis, Minnesota Press.

Bennett, N., Andreae, J., Hegarty, P. and Wade, B., 1980, Open Plan Schools, Windsor, Schools Council Publishing/NFER.

Brogden, M., 2007, 'Plowden and primary school buildings: A story of innovation without change', in Forum: For Promoting 3-19 Comprehensive Education, 49(1), 55-66.

Building Futures, 2004, 21st Century Schools: Learning Environments of the Future, London, Building Futures.

CABE (Commission for Architecture and the Built Environment), 2002, The Value of Good Design, London, CABE.

CABE (Commission for Architecture and the Built Environment), 2003, Creating Excellent Buildings: A Guide for Clients, London, CABE.

CABE (Commission for Architecture and the Built Environment), 2005,Picturing School Design, London, DfES.

CABE (Commission for Architecture and the Built Environment), 2006a, Better Public Buildings, London, HMSO. 
CABE (Commission for Architecture and the Built Environment), 2006b, Assessing Secondary School Design Quality, research report, London, CABE.

CABE (Commission for Architecture and the Built Environment), 2007, Creating Excellent Secondary Schools. A Guide for Clients, London, CABE.

Clark, H., 2002, Building Education: The Role of the Physical Environment in Enhancing Teaching and Research, London, Institute of Education.

Clements-Croome, D.J., 2004, 'Building environment, architecture and people', in D. ClementsCroome (ed), Intelligent Buildings: Design, Management and Operation, London, Thomas Telford.

Clements-Croome, D.J., 2006, Creating the Productive Workplace, 2nd edn, Abingdon, Taylor \& Francis.

DCMS (Department for Culture, Media and Sport), 2000, Better Public Buildings: A Proud Legacy for the Future, London, DCMS.

DfES (Department for Education and Skills), 2002, Schools for the Future: Designs for Learning Communities, Building Bulletin 95, London, DfES.

DfES (Department for Education and Skills), 2004a, Building Schools for the Future: A New Approach to Capital Investment, London, DfES.

DfES (Department for Education and Skills), 2004b, Exemplar Designs. Concepts and Ideas, London, DfES.

DfES (Department for Education and Skills), 2004c, Briefing Framework for Secondary School Projects: Building Bulletin 98, London, DfES. 
Dudek, M., 2000, Architecture of Schools: The New Learning Environments, Oxford, Architectural Press.

Earthman, G., 2000, 'The impact of school building conditions, student achievement, and behaviour', in The Appraisal of Investments in Educational Facilities, Paris, Organization for Economic Cooperation and Development.

Education and Skills Committee, 2007, Sustainable Schools: Are We Building Schools for the Future? Seventh Report of Session 2006-07, 1, House of Commons, London, HMSO.

Feilden, R., 2004, 'Design quality in new schools', in S. Macmillan (ed), Designing Better Buildings, London, E\&FN Spon.

Fisher, K., 2001, Building Better Outcomes. The Impact of School Infrastructure on Student Outcomes and Behaviour, Schooling Issues Digest, Department of Education, Training and Youth Affairs (DETYA), Australian Government.

Gann, D.M., Salter, A.S. and Whyte, J.K., 2003, 'Design quality indicator as a tool for thinking', in Building Research Information, 31(5), 318-333. Gump, P., 1987, 'School and classroom environments', in D. Stockol and I.Altman (eds), Handbook of Environmental Psychology, Vol 1, New York, Wiley.

Gifford, R., 2002, Environmental Psychology: Principles and Practice, Colville, WA, Optimal Books.

Green, D. and Turrell, P., 2004, 'School building investment and impact on pupil performance', in Facilities, 23(5/6), 253-261.

Herzberg, F., 1966, Work and the Nature of Man, Cleveland, OH, World Publishing Company. Higgins, S., Hall, E., Wall, K., Woolner, P. and McCaughey, C., 2005, The Impact of School Environments: A Literature Review, The University of Newcastle for the Design Council. 
HM Government, 2006, Better Public Building, London, Commission for Architecture and the Built Environment.

Horne-Martin, S., 2004, 'Environment-behaviour studies in the classroom', in Journal of Design and Technology Education, 9(2), 77-89.

Macmillan, S., 2004, 'Design as a value generator', in S. Macmillan (ed), Designing Better Building, London, Spon Press.

Macmillan, S., 2006, 'Added value of good design', in Building Research and Information, 34(3), 257-271.

NAO (National Audit Office), 2009, The Building Schools for the Future Programme: Renewing the Secondary School Estate, London, NAO.

OECD (Organization for Economic Cooperation and Development), 2004, 21st Century Learning Environments, Paris, OECD Publishing.

OECD (Organization for Economic Cooperation and Development), 2006, PEB Compendium of Exemplary Educational Facilities, 3rd edn, Paris, OECD Publishing.

OGC (Office of Government Commerce), 2007, Achieving Excellence 9: Design Quality. Achieving Excellence in Construction Procurement Guide, London, OGC.

PwC (PricewaterhouseCoopers), 2001, Building Performance: An Empirical Assessment of the Relationship between Schools Capital Investment and Pupil Performance, Research Report No 242, London, Department for Education and Employment.

PwC (PricewaterhouseCoopers), 2003, Building Better Performance: An Empirical Assessment of the Learning and Other Impacts of Schools Capital Investment, Research Report No 407, London, Department for Education and Skills. 
PwC (PricewaterhouseCoopers), 2007, Evaluation of Building Schools for the Future - 1st Annual Report, London, Department for Children, Schools and Families.

PwC (PricewaterhouseCoopers), 2008, Evaluation of Building Schools for the Future - 2nd Annual Report, London, Department for Children, Schools and Families.

Proshansky, H., Ittelson, W. and Rivlin, L., 1976, Environmental Psychology: People and their Physical Settings, New York, Holt, Rinehart and Winston.

Tanner, C.K., 2000, 'The influence of school architecture on academic achievement', in Journal of Educational Administration, 38(4), 309-330.

Vitruvius, P., 1999, Ten Books on Architecture (translated by I.D. Rowland), Cambridge, Cambridge University Press.

Woolner, P., Hall, E., Wall, K., Higgins, S., Blake, A. and McCaughey, C., 2005, School Building Programmes: Motivations, Consequences and Implications, Reading, University of Newcastle Upon Tyne.

Woolner, P., Hall, E., Higgins, S., McCaughey, C. and Wall, K., 2007, 'A sound foundation? What we know about the impact of environments on learning and the implications for Building Schools for the Future', in Oxford Review of Education,33(1), 47-70.

Weinstein, C., 1979, 'The physical environment of the school: A review of the research', in Review of Educational Research, 49(4), 577-610. 